\title{
EL HUMANISTA VICO
}

\author{
Jéssica Sánchez Espillaque \\ (Gr. de Inv. "Pensamiento Hispánico", \\ Universidad de Sevilla)
}

RESUMEN: La imagen de Vico que nos ha atraído siempre ha sido la del heredero del humanismo renacentista. Nuestra lectura de los textos viquianos se centran, por tanto, en averiguar los lazos de unión entre este filósofo y su tradición humanista. A través de la interpretación de E. Grassi hemos estudiado a un Vico que es el máximo representante de las principales ideas humanistas.

Palabras clave: Vico, $350^{\circ}$ Aniversario, Humanismo, Ernesto Grassi, Renacimiento, culminación, retórica, J. Sánchez Espillaque.

\section{The humanist Vico}

ABSTRACT: Vico has always attracted us as the heir of Renaissance humanism. Therefore, our reading of Vichian texts has aimed at finding out the links between this philosopher and his humanist tradition. Through the interpretation of E. Grassi we have studied Vico as the principal representative of the main humanist ideas.

KEYwORDS: Vico, 350 th Anniversary, Humanism, Ernesto Grassi, Renaissance, rhetoric, J. Sánchez Espillaque.

\section{Il Vico umanista}

RiASSUNTO: L'immagine di Vico che ha sempre attratto è stata quella dell'erede dell'umanesimo rinascimentale. Pertanto, la nostra lettura dei testi vichiani è incentrata sulla ricerca dei legami di unione tra questo filosofo e la tradizione umanista. Attraverso l'interpretazione di E. Grassi abbiamo studiato Vico come il massimo rappresentante delle principali idee umanistiche.

Parole ChiAVE: Vico, $350^{\circ}$ Anniversario, umanesimo, Ernesto Grassi, Rinascimento, culmine, retorica, J. Sánchez Espillaque.

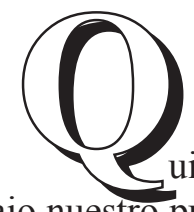

uizás una de las mejores versiones de Giambattista Vico se encuentre, bajo nuestro punto de vista, en su recurso al Humanismo renacentista. Esta dimensión del pensamiento viquiano es precisamente la que más ha llamado mi atención. Comencé a estudiar a Vico cuando realizaba mi Tesis Doctoral sobre la tradición humanista, dirigida por un cuidadoso estudioso de Vico, José Manuel Sevilla. Ya

Este artículo responde a una invitación expresa por parte de la Dirección de la Revista para este volumen especial por el $350^{\circ}$ Aniversario del nacimiento de G. Vico, habiendo superado los criterios de valoración y del proceso de aceptación. 
durante los cursos de doctorado pude conocer más de cerca el poder especulativo y, sobre todo, inventivo de la filosofía viquiana. Pero la Tesis me permitió conocer en profundidad las abundantes similitudes entre el pensamiento retórico humanista y el filósofo napolitano, de la mano de un autor, para mí, desconocido hasta ese momento: el filósofo milanés, discípulo de Martin Heidegger, Ernesto Grassi.

Mi lectura de Vico siempre ha estado, pues, atravesada por la tradición humanista de la que, en opinión de Grassi y de otros estudiosos, el humanista napolitano representa la culminación de su pensamiento renovador y clásico a la vez. Por ello, empecé a trabajar en la filosofía viquiana a propósito de su herencia humanista. En el filósofo napolitano llegan a término muchas de las ideas que humanistas del Renacimiento como Valla, Dante o Poliziano habían defendido doscientos años antes. Motivo principial por el que, y desde un punto de vista desacertado, se le había llegado a considerar como un pensador extranjero en su época o algo así como un renacentista tardío. Sin embargo, la recuperación y desarrollo de las principales tesis humanistas por parte de Vico no le apartaban de sus contemporáneos, sino que, más bien al contrario, lo reconducían al centro del debate en torno a la metodología de las ciencias. La revitalización humanista realizada por el autor de la Scienza nuova trataba de responder a la crisis cultural de la época y su prolusión universitaria de 1708 era una muestra de ello: en el De nostri temporis studiorum ratione Vico lleva a cabo un análisis de los métodos de estudios de su época en comparación con los antiguos, y descubre una serie de deficiencias educativas que son fruto de una educación demasiado rígida, que termina por destruir las facultades inventivas del niño al reprimir su fantasía, atrofiando así el sentido común y la imaginación. Razón por la cual el filósofo napolitano se opone a que el método científico tenga que comenzar por la crítica y no por la tópica. Debido a que semejante educación solo produce hombres enciclopédicos (que conocen mucho), pero que, sin embargo, no son sabios. La crítica de Vico al racionalismo cartesiano se centra, por tanto, en que este frustra la fantasía y el ingenio, entorpeciendo de este modo el camino de las lenguas, la historia, las artes y demás disciplinas humanísticas. De ahí que, para poder cultivarlas, Vico estime necesaria una vuelta a aquella tradición -que, por otro lado, era la suya propia- en la que sí que eran valoradas como una verdadera educación integral del hombre.

La presencia de Vico en mis investigaciones se había vuelto casi ineludible -por esta defensa que él hace de las humanidades- hasta el punto de que era muy difícil hablar del Humanismo renacentista y no mencionar siquiera el pensamiento viquiano. Como epígono del humanismo, nuestro autor está vivo en casi todos mis trabajos: desde una primera obra en torno a la tradición humanista, El problema histórico-filosófico del humanismo retórico renacentista, hasta una monografía sobre Ernesto Grassi y la filosofia del Humanismo, pasando por numerosos artículos de investigación, en los que Vico ha resultado ser un elemento fundamental en dicha 
tradición filosófica. Al igual que Grassi, considero a Vico una pieza clave en la rehabilitación actual del humanismo retórico renacentista, ya que tuvo el valor de rescatar de las tinieblas, cual humanista, las denostadas disciplinas humanísticas bajo el convencimiento de que otra educación, distinta de la racionalista, era posible. Por esta razón me resultan tan valiosas las palabras del filósofo napolitano, porque como continuador o, mejor dicho, restaurador del pensamiento humanista contribuyó, en una época nada proclive al pensamiento del humanismo, a que dicha tradición no cayera en el olvido.

Contrariamente a lo que pensaba Descartes, Vico defiende en sus obras la necesidad de una educación basada en los llamados studia humanitatis como fundamento para una formación más humana del hombre. En otras palabras, lo que más nos interesa de su pensamiento se halla en que ese proyecto de renovación pedagógica y científica que este autor lleva a cabo se basa en la relectura de las obras clásicas del pensamiento humanista. Luego, si mi intención ha sido y es, como lo fue para el filósofo italogermano, la de una revitalización actual del pensamiento retórico renacentista, estimo esencial dirigirnos a aquel autor en el que la filosofía humanista llega a su punto más alto. De ahí que la imagen que más me ha interesado de Vico haya sido la del heredero incuestionable del Humanismo renacentista.

De lo dicho podría deducirse, como efectivamente se ha hecho, la enorme actualidad del pensamiento viquiano. En mi caso, esa actualidad se traduce en una rehabilitación hoy en día de la tradición humanista. La vigencia actual de las ideas viquianas estriba, para nosotros, en su defensa de la dignidad filosófica de dicha tradición. Si no hubiera sido por Vico, además de otros autores aislados como Matteo Peregrini (1595-1652), Emmanuele Tesauro (1592-1675) o Ludovico A. Muratori (1672-1750), el humanismo renacentista habría caído seguramente en el olvido motivado por la crítica racionalista. Cabe recordar que el rechazo por parte de todo el racionalismo de los studia humanitatis se apoyaba principalmente en su creencia - del todo reduccionista- de que para alcanzar un conocimiento verdadero solo es necesario el uso de la razón. Quedando de este modo arrinconadas otras facultades del entendimiento humano como la imaginación, el ingenio o la fantasía, que fueron rechazadas por no moverse en el ámbito de la certeza sino más bien de lo verosímil. Sin embargo, para Vico, el lenguaje racional no es el único científico, sino que hay otro, anclado en el aquí y el ahora, basado en imágenes y metáforas, que es capaz de captar el carácter metamórfico de la realidad. Ese lenguaje retórico, poético, no apriorístico es el que permite al hombre conocer la individualidad y especificidad de la realidad (incluida la realidad humana), que lejos de ser cierta e indubitable cae en el ámbito de lo probable.

Vico parte de la conciencia de la naturaleza finita del hombre para postular la necesidad de un conocimiento humano que, a diferencia de las verdades geométricas, no puede ser medido y cuantificado. De acuerdo a la consideración viquiana, 
el mundo humano solo puede ser narrado desde una perspectiva poética y nunca encapsulado dentro de unos parámetros rígidos y universalmente válidos. Los únicos universales - los universales fantásticos- han de poder, mediante fábulas, explicar la realidad individual humana. Dicho en otros términos, haciendo uso de un lenguaje histórico, metafórico, y a través de una lógica ingeniosa, el hombre -explica nuestro autor- es capaz de conocerse y conocer el mundo que le rodea. Alejada de una lógica racionalista, obsesionada en la demostración universal de los entes, la ciencia viquiana -como representa magníficamente su grabado inicial- tiene el mérito de poder mostrar la realidad tal cual es, con sus sombras y sus luces, cargada de subjetividad, pero al mismo tiempo científica.

A lo largo de estos años de continuo diálogo con Vico he aprendido que la filosofía no puede basarse única y exclusivamente en el poder de la razón, sino que originariamente ha de expresarse poéticamente. El poder de la palabra metafórica, que tanto ha resaltado nuestro querido Grassi, alcanza en este humanista su máxima expresión, haciendo de la retórica una herramienta no solo necesaria para la vida civil sino un instrumento más de la filosofía.

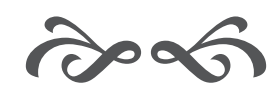

